\title{
The principal role of silicic crustal xenolith assimilation in the formation of Kimberley-type pyroclastic kimberlites - a petrographic study of the Renard 65 kimberlite pipe, Canada
}

\author{
Gaudet, M. ${ }^{1}$, Kopylova, M. ${ }^{1}$, Zhuk, V. ${ }^{2}$ \\ ${ }^{1}$ Department of Earth, Ocean and Atmospheric Sciences, Univeristy of British Columbia, \\ mgaudet@eoas.ubc.ca,mkopylova@eoas.ubc.ca \\ ${ }^{2}$ Stornoway Diamond Corporation,vzhuk@stornowaydiamonds.com
}

\begin{abstract}
Controversial issues regarding the emplacement processes for Kimberley type pyroclastic kimberlite (KPK) deposits have been 1) whether the pyroclastic textures in KPK rock types reflect the sole effects of magmatic exsolution during emplacement; and 2) whether the characteristic microlitic interclast matrix assemblage of diopside + phlogopite + serpentine in KPK rock types is the product of primary crystallization from the kimberlite magma and associated fluids, or a result of secondary hydrothermal metamorphism of the kimberlite deposit. Solutions to these problems are consequential to an improved understanding of the emplacement-related processes of kimberlite magmas and to the economic modelling of kimberlite deposits. Our extensive petrographic characterization of over $700 \mathrm{~m}$ of drill core from four drill hole intersections through the Renard 65 pipe, Quebec, Canada, provides new evidence on the principal role of silicic crustal xenolith assimilation in the formation of KPK deposits.
\end{abstract}

The Renard 65 pipe is infilled with two distinct phases of kimberlite encompassing rock types ranging in texture from hypabyssal kimberlite (HK) to Kimberley type pyroclastic kimberlite, including a complete suite of rock types with petrographic features intermediate between hypabyssal and Kimberley type pyroclastic kimberlite (HKt/KPKt). Kimb65A is a vertical and roughly cyllindrical body of Kimberley type pyroclastic kimberlite containing 40-90 \% modal abundance of crustal xenoliths, 5-15 $\%$ anhedral calcite-pseudomorphed olivine macrocrysts, and 10-20\% spherical magmaclasts containing calcite-pseudomorphed olivine phenocrysts in a groundmass of phlogopite + perovskite + spinel + apatite + titanite + calcite + serpentine; these components are set in a very-fine grained matrix of microlitic diopside + phlogopite + interstitial serpentine, along with heterogeneous distributions of primary perovskite + spinel + apatite. These KPK rock types have a massive and matrix-supported texture, with crustal xenoliths generally appearing sub-angular and weakly reacted. Kimb65B is also a vertical and roughly cylindrical body of kimberlite displaying a sharp, near-vertical contact with Kimb65A. Kimb65B consists of hypabyssal kimberlite in the center of the body, transitioning gradationally into rock types with textures intermediate between coherent kimberlite and Kimberley type pyroclastic kimberlite, towards the outer margins of the body. HK rock types in Kimb65B contain 15-30 \% modal abundance of crustal xenoliths, 20-25\% modal abundance of anhedral and partially serpentinized olivine macrocrysts, and 15-20\% modal abundance of subhedral to euhedral serpentinized olivine phenocrysts, all set in a primary groundmass of homogeneously distributed phlogopite + spinel + perovskite + apatite + calcite + serpentine. Crustal xenoliths hosted in HK rock types are of either a dominantly gneissic or granitic composition (representing clasts of a larger, banded, leucocratic granite-gneiss), and are always strongly reacted; they display $1-4 \mathrm{~cm}$ thick recrystallized zones composed of anhedral and fine-grained mixtures of calcite + serpentine + pectolite, and very thin sub-millimeter outer monomineralic coronas of diopside (zoned to aegirine), and phlogopite. Over a scale of meters to tens of meters in drill core towards the outer portions of the body of Kimb65B, the texture of the kimberlite changes gradationally towards a rock type in which the groundmass is defined by two distinct assemblages: 1) phlogopite + calcite + serpentine, and 2) microlitic diopside + phlogopite + serpentine. The diopside-rich assemblage forms a patchy texture on a cm-scale and is most pronounced proximal to reacted crustal xenoliths (Figure 1A); these rock types are referred to as HKt rock types. This diopside-rich groundmass assemblage becomes the more dominant assemblage as crustal xenoliths become more abundant towards the outer margins of the body of Kimb65b; these are referred to as KPKt rock types. This change in the mineralogy of the kimberlite groundmass from phlogopite + serpentine + calcite in HK rock types, to diopside + phlogopite + serpentine in transitional HK and KPK rock types, is interpreted to be a consequence of assimilation of silicic xenoliths and 
addition of $\mathrm{SiO}_{2}, \mathrm{Al}_{2} \mathrm{O}_{3}, \mathrm{FeO}, \mathrm{K}_{2} \mathrm{O}$ to the kimberlite magma during emplacement. The recrystallization of granitic xenoliths composed of quartz + orthoclase + albite + biotite to an assemblage of pectolite + serpentine + calcite required the addition of the components $\mathrm{CO}_{2}, \mathrm{H}_{2} \mathrm{O}, \mathrm{MgO}$ and $\mathrm{CaO}$, all of which would have been readily available in the kimberlite magma (Figure 1B); the components $\mathrm{SiO}_{2}, \mathrm{Al}_{2} \mathrm{O}_{3}$, $\mathrm{FeO}$ and $\mathrm{K}_{2} \mathrm{O}$ were produced during this recrystallization reaction (Reaction 1) (Figure 1B).

$$
\mathrm{qtz}+\text { or }+\mathrm{ab}+\mathrm{bt}+\mathrm{MgO}+\mathrm{CaO}+\mathrm{CO}_{2}+\mathrm{H}_{2} \mathrm{O} \rightarrow \mathrm{pct}+\mathrm{srp}+\mathrm{cal}+\mathrm{SiO}_{2}+\mathrm{Al}_{2} \mathrm{O}_{3}+\mathrm{FeO}+\mathrm{K}_{2} \mathrm{O}
$$

The consumption of $\mathrm{CO}_{2}$ and production of $\mathrm{SiO}_{2}$ during Reaction 1, and the reduction in the solubility of $\mathrm{CO}_{2}$ that would result from an increase in $\mathrm{wt} \% \mathrm{SiO}_{2}$ in the magma, stabilizes the crystallization of the diopside-rich assemblage over the diopside-free assemblage as illustrated by Reaction 2 after (Skinner \& Marsh, 2004):

$$
\mathrm{phl}+\mathrm{cal}+\operatorname{srp}+\mathrm{SiO}_{2}+\mathrm{MgO} \rightarrow \mathrm{di}+\mathrm{srp}+\mathrm{phl}+\mathrm{CO}_{2}
$$

These reactions are interpreted to have been initiated at magmatic temperatures, persisting into subsolidus temperatures, involving significant proportions of crustal xenoliths. The reactions demonstrate that the assimilation of crustal xenoliths and contamination of the kimberlite magmas primarily by Si may have resulted in the enhanced degassing of magmatic volatiles during emplacement. We modelled the effects of crustal xenolith assimilation on kimberlite melt composition and volatile exsolution using geologically constrained abundances of xenoliths in Renard 65 kimberlite and whole rock composition for granitic and gneissic in-situ country rock at Renard. The modelling indicates that $\mathrm{SiO}_{2}$ content may have increased by $4-9 \mathrm{wt} \%$ for KPKt rock types, and 6-13 wt\% for HK/HKt rock types. Based on an established negative correlation between the $\mathrm{SiO}_{2}$ content in melt and $\mathrm{CO}_{2}$ solubility (Moussallam et al., 2015), this translates into exsolution of 1.4-2 wt $\mathrm{CO}_{2}$ at a pressure equivalent depth of $3 \mathrm{~km}$. Therefore, a significant amount (4-20 rel. \%) of the $\mathrm{CO}_{2}$ exsolved during the final $3 \mathrm{~km}$ of emplacement may be in response to the assimilation of crustal xenoliths.
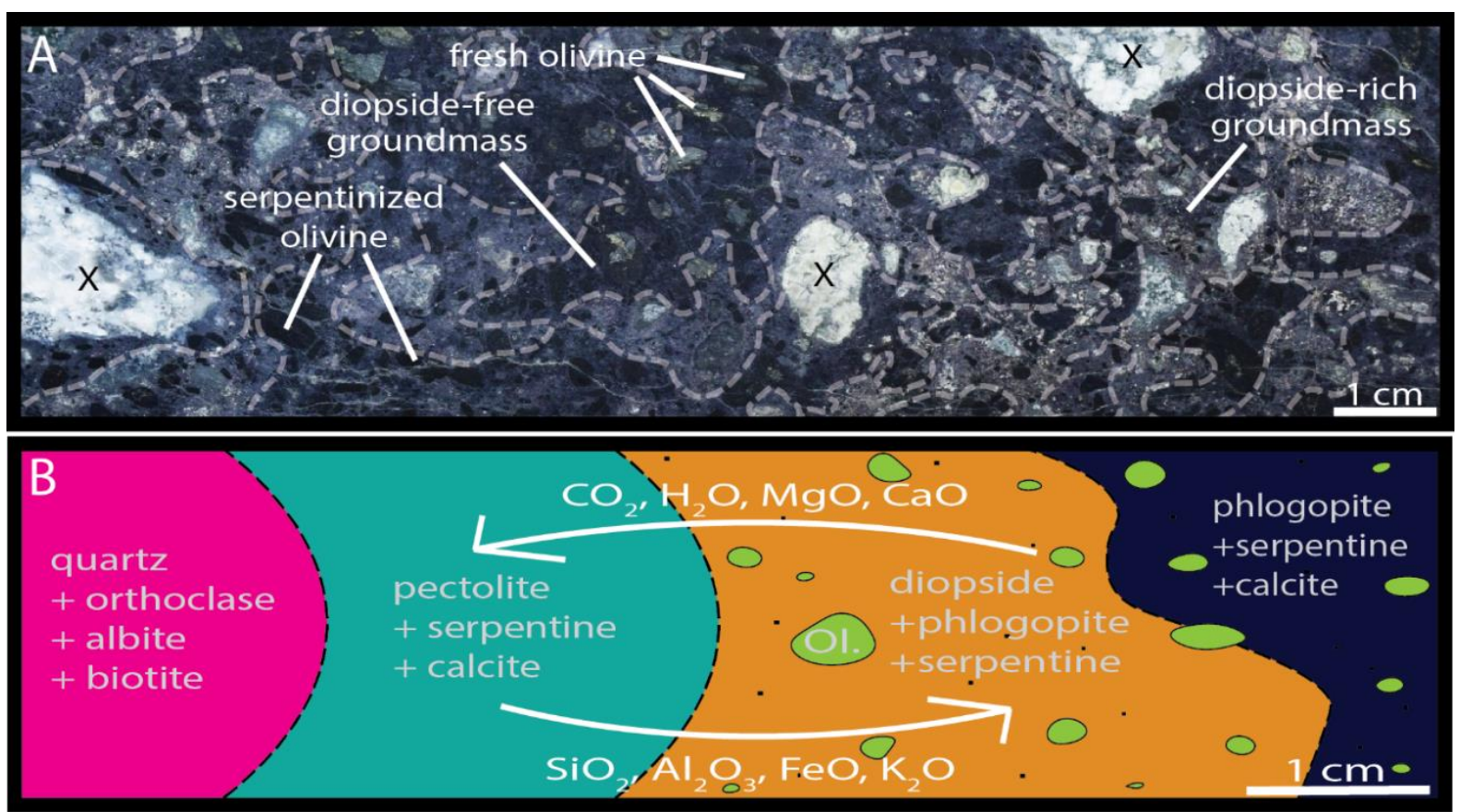

Figure 1 - (A) Transitional coherent kimberlite in polished slab viewed under a binocular microscope showing the patchy distribution of diopside-rich and diopside-free groundmass assemblages; crustal xenoliths are marked with an "x". (B) The granitic xenolith assemblage of quartz + orthoclase + albite + biotite reacts with oxides MgO, $\mathrm{CaO}, \mathrm{H}_{2} \mathrm{O}$ and $\mathrm{CO}_{2}$ in the kimberlite magma, recrystallizing the xenoliths to an assemblage of pectolite + serpentine + calcite and producing oxides $\mathrm{SiO}_{2}, \mathrm{Al}_{2} \mathrm{O}_{3}, \mathrm{FeO}$ and $\mathrm{K}_{2} \mathrm{O}$ which are assimilated by the kimberlite magma (Reaction 1). The increased activity of $\mathrm{SiO}_{2}$ in the kimberlite magma results in further exsolution of $\mathrm{CO}_{2}$ and crystallization of the hybrid groundmass assemblage diopside + phlogopite + serpentine (Reaction 2). Green grains labeled "Ol" are serpentinized olivine macrocrysts. 
The formation of KPK rock types in Renard 65 and associated rock types with textures intermediate between hypabyssal and Kimberley type pyroclastic kimebrlite reflects the spatial distribution of silicic crustal xenoliths within the magma during emplacement and crystallization. The existing models attributing the formation of KPK rock types to structurally controlled magmatic degassing and fluidization processes, or to hydrothermal alteration of pyroclastic material are inadequate in accounting for both 1) continuous pyroclastic KPK textures to an estimated $1.5 \mathrm{~km}$ below the original surface of Renard 65 in Kimb65A, and 2) continuous lateral gradations in rock texture from coherent kimberlite in the center of the body to KPKt towards the margins of Kimb65B. Our alternative model attributing magmatic devolatilization at least in part to the assimilation of silicic crustal xenoliths not only accounts for the distinct mineralogy and textures of Kimberley-type pyroclastic kimberlite rock types, but also for the spatial distribution of these rock types in Renard 65 and other similar kimberlite pipes at Renard and Gahcho Kue. These results further indicate that the differences in the diagnostic mineralogies and textures of Fort-à-la-Corne type and Kimberley type pyroclastic kimberlites may be influenced by the extent of assimilation of silicic crustal xenoliths driving the behavior of the kimberlite magma and magmatic volatiles during emplacement.

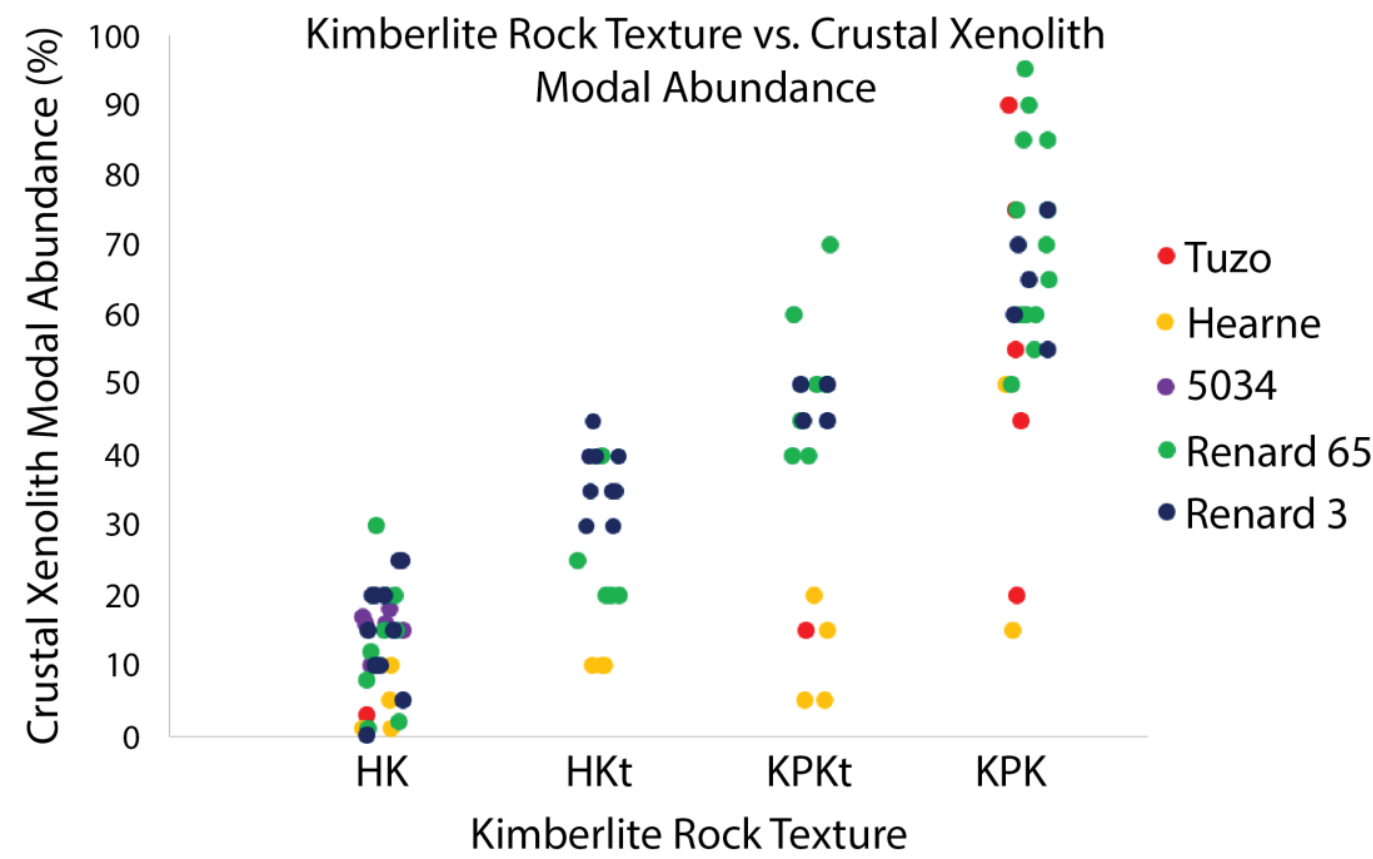

Figure 2 - Correlations between crustal xenolith modal abundances and kimberlite rock textures for kimberlites in multiple pipes from Gahcho Kue (Tuzo, Hearne, 5034) and Renard (Renard 2 \& Renard 65). Rock types with transitional to KPK textures in all pipes are associated with increased crustal xenolith modal abundances. Data for the Gahcho Kue pipes Tuzo, Hearne and 5034 are from drill hole summaries in Hetman et al. (2004), and data for the Renard pipes are from drill hole summaries in this research (Renard 65) and geological unit summaries (Renard 3 ) in Muntener \& Scott Smith (2013).

\section{References}

Hetman, C.M., Scott Smith, B.H., Paul, J.L., Winter, F.W., 2004. Geology of the Gahcho Kue kimberlite pipes, NWT, Canada: root to diatreme magmatic transition zones. Proceedings of the 8th International Kimberlite Conference. Lithos. 76, pp. 51-74.

Muntener, C., Scott Smith, B.H., 2013. Economic Geology of Renard 3, Quebec, Canada: A diamondiferous, multi-phase pipe, infilled with hypabyssal and Tuffisitic kimberlite. Proceedings of the 10th International Kimberlite Conference. 2, pp. 241-256.

Moussallam, Y., Morizet, Y., Gaillard, F., 2016. $\mathrm{H}_{2} \mathrm{O}-\mathrm{CO}_{2}$ solubility in low $\mathrm{SiO}_{2}$-melts and the unique mode of kimberlite degassing and emplacement. Earth and Planetary Science Letters. 447, pp. 151160.

Skinner, E.M.W., Marsh, S.J., 2004. Distinct kimberlite pipe classes with contrasting eruption processes. Lithos. 76, pp. 183-200. 